\title{
Kemampuan Menulis Puisi Pengaruh Media Pembelajaran dan Penguasaan Diksi
}

\author{
M. Sigit Goentoro \\ Universitas Indraprasta PGRI \\ Jalan Nangka No. 58 C/TB. Simatupang, Tanjung Barat, Jakarta Selatan 12530 \\ avril_dewa19@yahoo.com
}

\begin{abstract}
This study aims to determine the method of learning and instructional media on the ability to write poem. This study uses an experimental method, with a population of 796 students in states Jakarta in East Jakarta, and a random sampling technique obtained by 80 students. The statistical analysis technique used was two-way ANOVA at a significant level of $\alpha=0.05$. The results of the study proved that learning methods and mastery of sentences contributed to the ability to write exposition.
\end{abstract}

Keywords: Instructional media, Vocabulary Mastery, Poem Writing Ability.

\begin{abstract}
Abstrak
Penelitian ini bertujuan untuk mengetahui media pembelajaran dan penguasaan diksi terhadap kemampuan menulis puisi. Penelitian ini menggunakan metode eksperimen, dengan populasi siswa SMK Negeri di Jakarta Timur sejumlah 796 siswa, dan teknik sampling acak diperoleh sampel sebesar 80 siswa. Teknis analisis statistik yang dipergunakan adalah ANOVA dua jalur pada taraf signifikan $\alpha=0,05$. Hasil penelitian membuktikan bahwa media pembelajaran dan penguasaan diksi berkontribusi terhadap kemampuan menulis puisi.
\end{abstract}

Kata Kunci: Media Pembelajaran, Penguasaan Diksi, Kemampuan Menulis Puisi

\section{PENDAHULUAN}

Dalam kegiatan pendidikan di sekolah, keterampilan berbahasa merupakan salah satu kemahiran yang harus dikuasai siswa sejak kelas rendah. Dengan bahasa, manusia bisa berhubungan dengan manusia lainnya dan dengan bahasa pula komunikasi bisa terjalin. Oleh karena itu, dalam dunia pendidikan, pelajaran bahasa Indonesia diarahkan untuk meningkatkan kemampuan siswa untuk berkomunikasi dalam bahasa Indonesia secara efektif dan efisien sesuai dengan etika yang berlaku baik secara lisan maupun tulis, serta menumbuhkan apresiasi terhadap hasil karya kesastraan manusia Indonesia.

Menurut Tarigan (2008:1), keterampilan bahasa mempunyai empat komponen, yaitu keterampilan menyimak (listening skill); keterampilan membaca (reading skill); keterampilan berbicara (speaking skill); dan keterampilan menulis (writing skill).

Kemudian, muncul anggapan bahwa kemampuan menulis lebih sulit dikuasai dibandingkan dengan tiga kemampuan berbahasa yang lain (membaca, mendengarkan, dan berbicara). Hal tersebut dikarenakan kemampuan menulis menghendaki penguasaan berbagai unsur kebahasaan dan unsur di luar bahasa itu

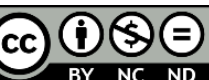

Creative Commons Attribution-NonCommercial-NoDerivatives 4.0 International License 
sendiri yang akan menjadi isi karangan. Baik unsur bahasa maupun unsur isi haruslah terjalin sedemikian rupa sehingga menghasilkan karangan yang runtut dan padu (Nurgiyantoro, 2001:240).

Keterampilan menulis mempunyai peranan yang sangat penting dalam kehidupan. Menulis dapat menunjang kesuksesan hidup seseorang. Dengan keterampilan menulis, seseorang dapat melibatkan diri dalam persaingan gobal yang saat ini terjadi. Melalui kegiatan ini, seseorang dapat mengaktualisasikan diri dan ikut menjadi bagian kemajuan zaman.

Dalam kenyataan yang peneliti dapat dari beberapa informasi baik siswa maupun para pengajar di sekolah, menunjukkan bahwa kemampuan menulis belum optimal dikuasai oleh siswa. Mereka kebanyakan menganggap bahwa menulis bukan sesuatu yang mudah untuk dilakukan. Menulis juga dianggap sebagai suatu kegiatan yang membosankan. Oleh karena itu, perlulah kiranya guru memadukan teknik pembelajaran dan media yang sesuai dalam upaya untuk memberikan alat bantu bagi siswa dalam menciptakan suasana yang efektif dalam pembelajaran menulis.

Kurangnya kebiasaan menulis pada siswa menyebabkan mereka sulit menuangkan ide-idenya dalam bentuk tulisan. Kondisi ini disebabkan oleh kenyataan bahwa pendekatan pembelajaran bahasa Indonesia di SMA masih bercirikan pendekatan struktural atau metode ceramah sehingga siswa kurang mampu mengungkapkan ide secara kreatif, logis, orisinal, dan menarik dalam bentuk tulisan.

Sementara itu, pengajaran sastra dapat membantu si anak didik untuk mendekati norma-norma dan pola-pola pemikiran masyarakatnya sendiri dengan kritis. Sifat sastra yang menyoroti pola-pola pemeranan serta hubungan-hubungan sosial dapat dipergunakan untuk menyadarkan seorang remaja (dalam hal ini siswa) mengenai kedudukannya di tengah masyarakat.

Pembiasaan terhadap karya sastra meningkatkan kecerdasan naratif, yaitu kemampuan memaknai secara kritis dan kemampuan memproduksi narasi. Sastra menawarkan ragam dan struktur cerita dari para penulis. Beberapa penelitian menunjukkan bahwa dibandingkan dengan pengajaran bahasa, pengajaran sastra lebih berkontribusi terhadap keterampilan menulis. Dengan membaca sastra, siswa dengan sendirinya tanpa disadari akan mengenal tata bahasa. Selain itu, apresiasi terhadap berbagai karya sastra meninggalkan pada benak siswa model-model karya sastra yang dapat dijadikan contoh dalam mengarang.

Dengan alasan-alasan di atas, pengajaran sastra perlu mendapat perhatian agar siswa memiliki keterampilan di dalam bersastra sehingga mampu mencurahkan isi hatinya kepada orang lain dengan baik. Jadi, siswa harus belajar dan berlatih untuk memperoleh kemampuan di dalam bersastra.

Salah satu cara kreatif untuk mengungkapkan ide dalam bentuk tulisan adalah dalam pembelajaran karya sastra dengan menulis puisi. Menulis puisi merupakan bagian dari menulis sastra bukan hanya sekadar menulis tulisan indah, tetapi kita pun harus tahu apa maksud dari tulisan indah itu. Menulis puisi yang ada di dalam aspek menulis merupakan bagian dari pembelajaran sastra yang diajarkan di sekolah (Djoko, 1993). 
Seperti yang telah dipaparkan sebelumnya ternyata dalam pembelajaran puisi masih terdapat hambatan seperti masih kurang kreativitasnya guru dalam mengembangkan media pembelajaran menulis puisi. Hal inilah yang menyebabkan pembelajaran puisi masih belum efektif. Hal tersebut disebabkan antara lain kurangnya waktu yang tersedia untuk mempelajari puisi secara lebih saksama, kurangnya minat siswa terhadap puisi dengan alasan pengajaran yang digunakan membosankan, dan banyak hal lain yang menyebabkan pembelajaran puisi dirasakan belum mencapai hasilnya (Arsyad, 1997).

Salah satu cara untuk menumbuhkan kencintaan siswa terhadap puisi adalah penggunaan media pembelajaran. Media tersebut bisa berupa media audiovisual, yaitu video klip dari sebuah lagu. Dalam video klip lagu tersebut terdapat beberapa dialog antara tokoh model video klip secara tersirat. Media video klip diharapkan dapat membantu siswa mengembangkan imajinasinya dalam bentuk puisi berdasarkan adegan yang dilihatnya dalam video klip. Selain itu, alasan dipilihnya media video klip karena dalam media ini terdapat musik dan lirik lagu yang banyak dikenal oleh para siswa (Suleiman, 1985).

Selain media pembelajaran, masalah lain yang muncul dalam menulis puisi adalah penguasaan diksi. Penggunaan diksi dalam puisi siswa masih terbatas bahkan banyak yang mengulang atau meniru puisi lain yang sudah ada. Seharusnya Penggunaan bahasa dalam puisi disusun sebaik mungkin menggunakan diksi dan tata bahasa yang menarik. Hal ini lah yang menyebabkan puisi menjadi indah (Martono, 2013). Berdasarkan pengamatan sementara, penulis menduga keterbatasan penggunaan diksi menunjukkan penguasaan diksi yang dimiliki oleh siswa masih rendah.

Dari beberapa uraian di atas, penulis tertarik untuk meneliti dengan mengaitkan beberapa variabel yang merupakan beberapa faktor yang mendukung atau mempengaruhi kemampuan menulis puisi yakni media pembelajaran dan penguasaan diksi siswa yang kemudian terangkai dengan tema media pembelajaran dan penguasaan diksi siswa terhadap kemampuan menulis teks puisi khususnya untuk siswa SMK

\section{METODE}

Penelitian ini berbentuk penelitian lapangan dan media yang digunakan adalah media survei. Menurut Sugiyono (2008:6), media penelitian pendidikan dapat diartikan sebagai cara ilmiah untuk mendapatkan data yang valid dengan tujuan dapat ditemukan, dikembangkan, dan dibuktikan, suatu pengetahuan tertentu sehingga pada gilirannya dapat digunakan untuk memahami, memecahkan, dan mengantisipasi masalah dalam bidang pendidikan. Berdasarkan sampel data yang akan diteliti, media yang digunakan dalam penelitian ini adalah media eksperimen.

Berdasarkan pengertian pakar di atas maka penulis menarik kesimpulan bahwa media eksperimen untuk digunakan dalam penelitian ini karena sesuai dengan maksud dan tujuan penelitian.

Variabel penelitian ini terdiri dari variabel terikat, yaitu kemampuan menulis puisi (Y) dan dua variabel bebas, yaitu media pembelajaran $\left(\mathrm{X}_{1}\right)$, dan

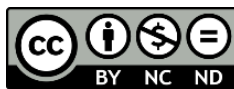


penguasaan diksi $\left(\mathrm{X}_{2}\right)$, maka model konstelasi hubungan antarvariabel dalam penelitian ini adalah sebagai berikut:

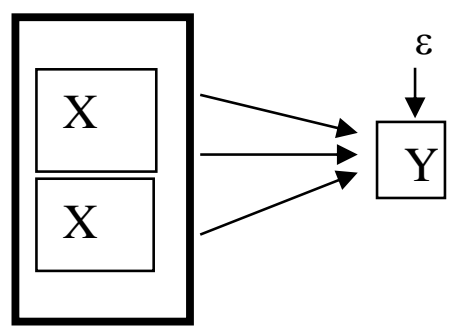

\title{
Gambar1. Konstelasi hubungan antar variabel penelitian
}

\author{
Keterangan: \\ Variabel Bebas $\left(\mathrm{X}_{1}\right)$ : Media pembelajaran \\ Variabel Bebas $\left(\mathrm{X}_{2}\right)$ : Penguasaan diksi \\ Variabel (Y) : Kemampuan menulis teks puisi \\ $\varepsilon \quad$ : Variabel lain yang tidak diteliti
}

Berdasarkan konstelasi hubungan antarvariabel penelitian, maka penulis menyimpulkan bahwa media eksperimen cocok digunakan dalam penelitian ini karena sesuai dengan tujuan penelitian. Tujuan penelitian ini untuk memperoleh gambaran media pembelajaran (variabel $\mathrm{X}_{1}$ ) dan penguasaan diksi ( variabel $\mathrm{X}_{2}$ ) terhadap kemampuan menulis puisi. $\mathrm{X}_{1}$ dan $\mathrm{X}_{2}$ merupakan variabel bebas pertama dan kedua serta $\mathrm{Y}$ adalah variabel terikat. Peneliti menggunakan media eeksperimen yang merupakan bagian dari jenis penelitian kuantitatif.

Populasi dalam penelitian ini adalah seluruh siswa kelas X SMK Negeri di wilayah Jakarta Timur tahun pelajaran 2018/2019. Dalam penelitian ini peneliti membatasi hanya dua sekolah negeri yaitu siswa kelas X di SMK Negeri 10 Jakarta dan SMK Negeri 22 Jakarta yang dijadikan sebagai populasi.

Penulis melakukan pengambilan sampel untuk mendapatkan data-data tentang variabel penelitian yang lebih lengkap dan akurat, penulis menetapkan ukuran atas jumlah sampel, yaitu sebesar $10 \%$ dari seluruh populasi dengan menggunakan teknik multi stage sampling dengan tahapan sebagai berikut: sampel ditarik dari kelompok populasi tetapi tidak semua anggota kelompok populasi menjadi anggota sampel hanya sebagian dari anggota subpopulasi menjadi anggota sampel. Caranya bisa dengan equal probability ataupun dengan proportional probability. Pada equal probaliti maka dari tiap kelompok populasi kita pilih sejumlah anggota tertentu untuk dimasukkan ke dalam sampel dan tiap anggota kelompok tersebut mempunyai probabilitas yang sama untuk dimasukkan ke dalam sampel.

Pada proportional probaliti, tiap anggota kelompok mempunyai probabilitas yang sebanding dengan besar relatif dari kelompok-kelompok yang dimasukkan dalam subsampel.

Bahwa sampel yang akan diteliti sebanyak 80 siswa dengan jumlah populasi sebanyak 792 siswa dari dua SMK Negeri di Kota Administrasi Jakarta Timur dengan perinciannya 360 siswa SMK Negeri 10 Jakarta dan 432 siswa SMK Negeri 
22 Jakarta sehingga jumlahnya 792 siswa. Jumlah sampel SMK Negeri 10 Jakarta sebanyak 40 siswa dan sampel SMK Negeri 22 Jakarta sebanyak 40 siswa. Dengan ketentuan tersebut, jumlah sampel telah memenuhi syarat untuk mewakili populasi.

Instrumen dalam penelitian ini sebagaimana dijelaskan di atas, bahwa ada tiga jenis data yang dikumpulkan dalam penelitian ini. Ketiga sumber data tersebut didasarkan pada tiga variabel penelitian, yakni data tentang variabel bebas $\left(\mathrm{X}_{1}\right)$, yaitu media pembelajaran, Variabel bebas $\left(\mathrm{X}_{2}\right)$, yaitu penguasaan diksi dikumpulkan melalui tes dan variabel terikat (Y) yaitu kemampuan menulis puisi yang dikumpulkan dengan menggunakan tes menulis. Data kemudian dianalisis dengan SPSS 20.

\section{HASIL DAN PEMBAHASAN}

Hasil pengujian penelitian ini didapatkan data sebagai berikut: Data kemampuan menulis puisi diperoleh sebanyak 80 siswa yang menjadi sampel penelitian.

Penelitian ini merupakan eksperimen dua faktor ialah faktor media pembelajaran (A) dan penguasaan diksi (B). Masing-masing faktor terdiri dari sub faktor yang disebut level. Untuk faktor media pembelajaran ada dua level yaitu level eksperimen dengan media video klip (A1) dan level kontrol dengan media konvensional (A2). Faktor kedua adalah penguasaan diksi dengan dua level, pertama penguasaan diksi tinggi (B1), kedua penguasaan diksi rendah (B2).

Tabel 1. Rangkuman Statistik Deskriptif

Dependent Variable: Kemampuan Menulis Puisi

\begin{tabular}{llrrr}
\hline $\begin{array}{c}\text { Media } \\
\text { Pembelajaran }\end{array}$ & \multicolumn{1}{c}{$\begin{array}{c}\text { Penguasaan } \\
\text { Diksi }\end{array}$} & Mean & $\begin{array}{c}\text { Std. } \\
\text { Deviation }\end{array}$ & N \\
\hline Media & Tinggi & 85.30 & 4.169 & 20 \\
pembelajaran & Rendah & 87.25 & 2.359 & 20 \\
& Total & 86.28 & 3.486 & 40 \\
Konvensional & Tinggi & 81.60 & 3.315 & 20 \\
& Rendah & 78.00 & 5.311 & 20 \\
& Total & 79.80 & 4.735 & 40 \\
Total & Tinggi & 83.45 & 4.163 & 40 \\
& Rendah & 82.63 & 6.196 & 40 \\
& Total & 83.04 & 5.261 & 80 \\
\hline
\end{tabular}

Berdasarkan data ini menunjukkan bahwa untuk kelas eksperimen (A1) mempunyai rata-rata 85,30 lebih besar dibandingkan kelas kontrol dengan nilai rata-rata sebesar 81,60 . Secara deskriptif menunjukkan bahwa eksperimen dapat dinyatakan berhasil.

Uji normalitas pada variabel dependen dan atau variabel kovariate diperlukan. Utamanya apakah media analisis selanjutnya menggunakan statistik parametrik atau nonparametrik. Jika data mengikuti suatu tes normalitas atau tes 
distribusi teoretis lainnya, maka dapat dilanjutkan analisisnya dengan statistik parametrik. Misalnya pada penelitian ini akan dilanjutkan dengan analisis parametrik tertentu, ialah Analysis of Variance (ANOVA) atau menggunakan analisis general linear model (GLM).

Berdasarkan tabel 2. menunjukkan bahwa kemampuan menulis resensi (Y). Data ini diuji mengikuti distribusi teoretis apa, apakah mengikuti distribusi normal, binominal, Poisson, Unform, exponential, atau lainnya. Umumnya menggunakan tes normalitas. Apabila ternyata mengikuti salah satu distribusi teoretis, maka dilanjutkan dengan analisis parametrik yang sudah ditentukan sebelumnya. Atau dapat ditentukan kemudian setelah uji parametrik dilakukan (hal ini tidak umum dilakukan peneliti, karena statistik apa yang akan dipakai sudah ditentukan sebelumnya). Berdasarkan data pada tabel 4.2 menunjukkan bahwa pengujian normalitas kemampuan menulis resensi (Y) menggunakan statistik tes Kolmogorov Smirnov (KS) yang disajikan pada tabel tersebut.

\section{Tabel 2. Uji Normalitas}

\section{One-Sample Kolmogorov-Smirnov Test}

\begin{tabular}{lllr}
\hline & & Kemampuan \\
Puisi & Menulis \\
Normal Parameters & & 80 \\
& & & 83.04 \\
Most Extreme Differences & Mean & & 5.261 \\
& Std. Deviation & .108 \\
& Absolute & .068 \\
Kolmogorov-Smirnov Z & Positive & -.108 \\
Asymp. Sig. (2-tailed) & Negative & .965 \\
a. Test distribution is Normal. & & .309 \\
b. Calculated from data. & & \\
\hline
\end{tabular}

Berdasarkan tabel tersebut menunjukkan bahwa nilai uji statistik KS untuk kemampuan menulis puisi sama dengan 0,965 dan Sig.= 0,309 > 0,05 yang berarti data kemampuan menulis puisi berdistribusi normal.

Selain uji normalitas, salah satu syarat yang diperlukan dalam menganalisis data dengan menggunakan ANOVA adalah uji homogenitas varian. Adapun tujuan uji homogenitas adalah untuk mengetahui apakah varian populasi menurut kelompok yang dirancang bersifat homogen atau tidak. Hal ini juga sering disebutkan apakah kelompok-kelompok objek penelitian itu terdiri dari satu populasi (homogen) atau tidak.

\section{Tabel 3. Uji Homogenitas}

\section{Levene's Test of Equality of Error Variances ${ }^{a}$}

Dependent Variable: Kemampuan Menulis Puisi

\begin{tabular}{|c|c|c|}
\hline $\mathrm{F}$ & df1 df2 & Sig. \\
\hline
\end{tabular}




\section{Diskursus: Jurnal Pendidikan Bahasa Indonesia}

Vol. 2, No. 2, Agustus 2019, pp. 189-197

p-ISSN: 2615-4935

e-ISSN: 2615-4943

$\begin{array}{llll}4.160 & 3 & 76 & .009\end{array}$

Tests the null hypothesis that the error variance of the dependent variable is equal across groups.

a. Design: Intercept $+\mathrm{A}+\mathrm{B}+\mathrm{A} * \mathrm{~B}$

Pengujian homogenitas pada data kemampuan menulis puisi (Y) dilakukan dengan uji Levene's pada tahap signifikansi $\alpha=5 \%$. Ringkasan hasil perhitungan uji homogenitas pada tabel 4.3 menunjukkan bahwa tabel tersebut mempunyai F0 $=4.160$ dan Sig. = 0,009>0,05 untuk variabel dependen kemampuan menulis puisi.

Dengan demikian hipotesis nol diterima. Ini berarti bahwa sampel dari populasi yang memiliki varian homogen. Hal ini berlaku. Dari pengujian normalitas dan homogenitas dapat disimpulkan bahwa persyaratan yang harus dipenuhi oleh data penelitian akan diolah dengan teknik ANOVA sudah dipenuhi.

Setelah melakukan uji normalitas dan homogenitas dan hasilnya menunjukkan bahwa sampel penelitian berasal dari populasi berdistribusi normal dan varian sampel homogen, maka pengujian hipotesis dengan menggunakan ANOVA dapat dilakukan.

Analisis terhadap data kemampuan menulis puisi siswa dilakukan dengan menggunakan ANOVA dua arah yang proses perhitungannya dibantu dengan program SPSS 20 for Windows. Hasil uji ANOVA tersebut kemudian dilanjutkan dengan uji t untuk mengetahui signifikansi perbedaan diantara masing-masing kelompok secara signifikan (simple effect). Dengan kata lain, uji t digunakan dengan tujuan untuk melihat kelompok sampel mana yang lebih tinggi kemampuan menulis puisinya ditinjau dari tingkat kebiasaan menulis puisi. Adapun ringkasan hasil analisis data dengan menggunakan ANOVA dapat dilihat pada tabel berikut ini

\section{Tabel 4. Uji Hipotesis Penelitian}

\section{Tests of Between-Subjects Effects}

\begin{tabular}{llllll}
\hline \multicolumn{6}{l}{ Dependent Variable: Kemampuan Menulis Puisi } \\
\hline Source & $\begin{array}{l}\text { Type III Sum of } \\
\text { Squares }\end{array}$ & df & Mean Square & F & Sig. \\
Corrected Model & $1006.138^{\mathrm{a}}$ & 3 & 335.379 & 21.587 & .000 \\
Intercept & 551618.113 & 1 & 551618.113 & 35505.379 & .000 \\
$\mathrm{~A}$ & 838.513 & 1 & 838.513 & 53.972 & .000 \\
$\mathrm{~B}$ & 13.613 & 1 & 13.613 & .876 & .352 \\
$\mathrm{~A} * \mathrm{~B}$ & 154.013 & 1 & 154.013 & 9.913 & .002 \\
Error & 1180.750 & 76 & 15.536 & & \\
Total & 553805.000 & 80 & & & \\
Corrected Total & 2186.888 & 79 & & & \\
a. R Squared $=.460$ (Adjusted R Squared $=.439)$ &
\end{tabular}

Berdasarkan data di atas maka hipotesis yang diajukan dapat terjawab. Adapun penjelasan mengenai pembahasannya adalah sebagai berikut.

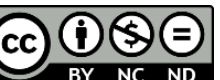

Creative Commons Attribution-NonCommercial-NoDerivatives 4.0 International License 
Berdasarkan tabel mengenai ringkasan hasil ANOVA di atas (output SPSS) terlihat bahwa nilai $\mathrm{F}_{\mathrm{h}}=53,972$ dan Sig. $=0,000<0,05$, maka hipotesis nol $\left(\mathrm{H}_{0}\right)$ ditolak dan hipotesis alternatif $\left(\mathrm{H}_{1}\right)$ diterima. Hal ini membuktikan bahwa perbedaan rerata (mean) kemampuan menulis puisi siswa yang diajar dengan menggunakan media pembelajaran dengan siswa yang diajar menggunakan media konvensional adalah berbeda secara signifikan. Siswa yang diajar menggunakan media pembelajaran memiliki kemampuan menulis puisi yang lebih tinggi daripada siswa yang diajar dengan media konvensional.

Berdasarkan data tersebut, dapat disimpulkan bahwa terdapat pengaruh yang signifikan antara media pembelajaran dengan kemampuan menulis puisi siswa. Dengan kata lain, terdapat perbedaan hasil belajar siswa yang diajar dengan menggunakan media audiovisual dengan siswa yang diajar media konvensional.

Berdasarkan tabel ANOVA (output SPSS) terlihat bahwa nilai $\mathrm{H}_{0}=0,876$ dan Sig. $=0,352<0,05$ maka hipotesis nol $\left(\mathrm{H}_{0}\right)$ ditolak dan hipotesis alternatif $\left(\mathrm{H}_{1}\right)$ diterima. Hal ini membuktikan bahwa perbedaan rerata (mean) kemampuan menulis puisi siswa yang mempunyai penguasaan diksi tinggi dengan siswa yang mempunyai penguasaan diksi rendah pada pelajaran menulis puisi adalah perbedaan yang signifikan. Siswa yang mempunyai penguasaan diksi tinggi dan siswa yang mempunyai penguasaan diksi rendah memiliki perbedaan yang signifikan. Berdasarkan data tersebut dapat disimpulkan bahwa terdapat pengaruh penguasaan diksi siswa pada materi menulis puisi terhadap kemampuan menulis puisi siswa. Dengan kata lain, terdapat perbedaan kemampuan menulis puisi siswa yang memiliki penguasaan diksi tinggi dengan siswa yang memiliki penguasaan diksi rendah pada pelajaran menulis puisi.

Berdasarkan tabel mengenai ringkasan hasil ANOVA (output SPSS) terlihat bahwa nilai $\mathrm{F}_{\mathrm{h}}=9,913$ dan Sig. $=0,002<0,05$, maka hipotesis nol $\left(\mathrm{H}_{0}\right)$ ditolak dan hipotesis alternatif $\left(\mathrm{H}_{1}\right)$ diterima. Hal ini membuktikan bahwa interaksi media pembelajaran dan kebiasaan menulis terhadap kemampuan menulis puisi signifikan. Adjusted R. Squared sebesar 0,439 berarti variabilitas kemampuan menulis puisi yang dapat dijelaskan oleh variabel media pembelajaran dan penguasaan diksi sebesar 43,9\%.

Berdasarkan hasil ANOVA, terlihat bahwa interaksi yang terjadi antara media pembelajaran dan penguasaan diksi pada pembelajaran merupakan interaksi yang signifikan. Karena adanya interaksi, maka dilakukan analisis lanjutan untuk melihat sample effect di antara sub-sub faktor yang membangun interaksi tersebut.

\section{SIMPULAN}

Berdasarkan data yang diperoleh dan hasil analisis yang dilakukan maka dapat ditarik kesimpulan sebagai berikut: 1) Terdapat pengaruh interaktif yang signifikan media pembelajaran dan penguasaan diksi terhadap kemampuan menulis puisi siswa SMK Negeri di Jakarta Timur. Hal ini dibuktikan dengan perolehan nilai Sig. $=0,002<0,05$ dan $\mathrm{Fh}=9,913 ; 2$ ) Terdapat pengaruh yang signifikan media pembelajaran terhadap kemampuan menulis puisi siswa SMK Negeri di Jakarta Timur. Hal ini dibuktikan dengan perolehan nilai Sig. $=0,000<0,05$ dan $\mathrm{Fh}=$ 
53,972 ; 3) Terdapat pengaruh yang signifikan penguasaan diksi terhadap kemampuan menulis puisi siswa SMK Negeri di Jakarta Timur. Hal ini dibuktikan dengan perolehan nilai Sig. $=0,352<0,05$ dan $\mathrm{Fh}=0,876$. Dengan demikian, media pembelajaran dan penguasaan diksi memiliki pengaruh terhadap kemampuan menulis puisi siswa.

\section{DAFTAR PUSTAKA}

Arsyad, A. (1997). Media pembelajaran. Jakarta. Rajawali Press.

Djoko, P. R. (1993). Pengkajian puisi. Yogyakarta. Gadjah Mada University Press.

Gani, R. (1988). Pengajaran sastra Indonesia, respond and analisis. Jakarta. Departemen Pendidikan.

Martono, Y. (2013). Tinjauan Stilistika dalam Kumpulan Puisi "Aku Manusia" Karya A. Mustofa Bisri. Jurnal NOSI, 1(7), 806-816.

Nurgiyantoro, B. (2001). Penilaian dalam pengajaran bahasa dan sastra. BPFEYogyakarta.

Sugiyono, (2008). Metode Penelitian Kualitatif dan Kuantitatif. Bandung: Remaja Rosdakarya.

Suleiman, A. H. (1985). Media audio-visual. Untuk pengajaran, penerangan dan penyuluhan. Jakarta. Gramedia.

Tarigan, H. G. (2008). Menulis sebagai suatu keterampilan berbahasa. Bandung. Angkasa. 